Pesq. Vet. Bras. 35(8):716-724, agosto 2015

DOI: $10.1590 / \mathrm{S} 0100-736 \mathrm{X} 2015000800003$

\title{
Pasteurella multocida type A as the primary agent of pneumonia and septicaemia in pigs $^{1}$
}

\author{
João X. de Oliveira Filho², Marcos A.Z. Morés ${ }^{3}$, Raquel Rebelatto ${ }^{3}$, Alais M.D. Agnol ${ }^{4}$, \\ Camila L.A. Plieski ${ }^{5}$, Catia S. Klein ${ }^{3}$, David E.S.N. Barcellos ${ }^{2}$ and Nelson Morés ${ }^{3 *}$
}

\begin{abstract}
Oliveira Filho J.X., Morés M.A.Z., Rebelatto R., Agnol A.M.D., Plieski C.L.A., Klein C.S., Barcellos D.E.S.N. \& Morés N. 2015. Pasteurella multocida type A as the primary agent of pneumonia and septicaemia in pigs. Pesquisa Veterinária Brasileira 35(8):716724. Embrapa Suínos e Aves, Rodovia BR-153 Km 110, Cx. Postal 21, Distrito de Tamanduá, Concórdia, SC 89700-000, Brazil. E-mail: nelson.mores@embrapa.br

In order to understand better the pathological aspects and spread of Pasteurella multocida type A as the primary cause of pneumonia in pigs, was made an experiment with intranasal inoculation of different concentrations of inocula [Group (G1): $10^{8}$ Colony Forming Units (CFU)/ml; G2: $10^{7} \mathrm{CFU} / \mathrm{ml}$; G3: $10^{6} \mathrm{CFU} / \mathrm{ml}$ and G4: $10^{5} \mathrm{CFU} / \mathrm{ml}$, using two pigs per group. The pigs were obtained from a high health status herd. Pigs were monitored clinically for 4 days and subsequently necropsied. All pigs had clinical signs and lesions associated with respiratory disease. Dyspnoea and hyperthermia were the main clinical signs observed. Suppurative cranioventral bronchopneumonia, in some cases associated with necrosuppurative pleuropneumonia, fibrinous pericarditis and pleuritic, were the most frequent types of lesion found. The disease evolved with septicaemia, characterized by septic infarctions in the liver and spleen, with the detection of $P$. multocida type A. In this study, P. multocida type A strain \#11246 was the primary agent of fibrinous pleuritis and suppurative cranioventral bronchopneumonia, pericarditis and septicaemia in the pigs. All concentrations of inoculum used $\left(10^{5}-10^{8} \mathrm{CFU} / \mathrm{ml}\right)$ were able to produce clinical and pathological changes of pneumonia, pleuritis, pericarditis and septicemia in challenged animals.
\end{abstract}

INDEX TERMS: Swine pasteurellosis, necrosuppurative pleuropneumonia, sepsis.

RESUMO.- [Pasteurella multocida tipo A como agente primário de pneumonia e septicemia em suínos.] Para entender melhor os aspectos patológicos e disseminação de Pasteurella multocida tipo A como causa primária de pneumonia em suínos foi realizado um experimento com inoculação intranasal de diferentes concentrações de inóculos [Grupo (G1): 10 Unidades Formadoras de Colônias

\footnotetext{
${ }^{1}$ Received on December 4, 2014.

Accepted for publication on May 6, 2015

${ }^{2}$ Programa de Pós-Graduação em Ciências Veterinárias, Departamento de Medicina Animal, Universidade Federal do Rio Grande do Sul (UFRGS), Agronomia, Av. Bento Gonçalves 9090, Porto Alegre, RS 91540-000, Brazil.

${ }^{3}$ Embrapa Suínos e Aves, Rodovia BR-153 Km 110, Cx. Postal 21, Distrito de Tamanduá, Concórdia, SC 89700-000, Brazil. *Corresponding author: nelson.mores@embrapa.br

${ }^{4}$ Faculdade de Medicina Veterinária, Universidade do Oeste de Santa Catarina (Unoesc), Campus II, Xanxerê, SC 89820-000, Brazil.

${ }^{5}$ Centro de Ciências Agroveterinárias, Universidade do Estado de Santa Catarina (UDESC), Lages, SC 88520-000, Brazil.
}

(UFC)/ml; G2: $10^{7} \mathrm{UFC} / \mathrm{ml}$; G3: $10^{6} \mathrm{UFC} / \mathrm{ml}$ e G4: $10^{5} \mathrm{UFC} /$ $\mathrm{ml}$ ], usando dois suínos por grupo. Esses suínos foram obtidos de um rebanho de alto status sanitário. Os animais foram monitorados clinicamente por quarto dias e subsequentemente necropsiados. Todos os suínos apresentaram sinais clínicos e lesões associadas com doença respiratória. Dispneia e hipertermia foram os principais sinais clínicos observados. Broncopneumonia cranioventral supurativa, em alguns casos associados com pleuropneumonia necrossupurativa, pleurites e pericardite fibrinosa foram mais frequentes. A doença evoluiu com septicemia, caracterizada por infartos sépticos no fígado e baço, com detecção de P. multocida. Neste estudo, P. multocida tipo A isolado 11246 foi agente primário de pleurite fibrinosa e broncopneumonia cranioventral supurativa, pericardite fibrinosa e septicemia em suínos. Todas as concentrações de inóculo utilizado $\left(10^{5}-10^{8} \mathrm{UFC} / \mathrm{ml}\right)$ foram capazes de produzir sinais clínicos e patológicos de alterações de pneumonia, pleurites, pericardites e septicemia nos animais. 
TERMOS DE INDEXAÇÃO: Pasteurelose suína, pleuropneumonia necrossupurativa, septicemia.

\section{INTRODUCTION}

Respiratory diseases are responsible for significant economic losses in pig production (Sørensen et al. 2006). Pasteurella multocida is one of the bacterial agents most commonly isolated from pneumonic lesions in pigs (Falk et al. 1991, Høie et al. 1991, Choi et al. 2003). This bacterial species belongs to the family Pasteurellaceae, which includes other species associated with pneumonia and polyserositis in pigs, such as Actinobacillus pleuropneumoniae and Haemophilus parasuis, respectively (Vanalstine 2012). Typically, $P$. multocida is regarded as a secondary opportunistic agent of enzootic pneumonia caused by Mycoplasma hyopneumoniae (Pijoan \& Fuentes 1987, Hansen et al. 2010). In addition to secondary role in bronchopneumonia, $P$. multocida may cause pleuritis, pericarditis (Pijoan \& Fuentes 1987, Ono et al. 2003, Pors et al. 2011a) and necrohemorrhagic pneumonia, similar to that caused by A. pleuropneumoniae ("A. pleuropneumoniae-like") (Cappuccio et al. 2004).

The successful experimental reproduction of porcine pneumonia by $P$. multocida has been achieved only when associated with other agents (Ross 2006). A preliminary study (Kich et al. 2007) verified that a field isolate of P. multocida type A was able to cause marked fibrinous pleuritis and pericarditis and focal necrohemorrhagic pneumonia (A. pleuropneumoniae-like lesions) after intranasal inoculation. Doses of $2.6 \times 10^{7}$ and $2.1 \times 10^{8}$ colony forming units $(\mathrm{CFU}) / \mathrm{ml}$ were used in this study (each pig received 1.5 $\mathrm{ml} /$ nostril of the inoculum). As a result, the aim of the present study was to establish an experimental model for reproducing pneumonia and systemic lesions characterized by serositis and septicemia following sole inoculation of $P$. multocida type A strain 11246 in pigs.

\section{MATERIALS AND METHODS}

Ethics statement. The experiment was conducted at Embrapa Swine and Poultry Research Centre, Concordia/SC, Brazil, in compliance with the Ethics Principles in Animal Experimentation, being approved by the Ethics Committee on Animal Experimentation (CEUA/CNPSA) (Protocol \#005/2010).

Animal houses. Eight $50 \mathrm{~kg}$ Body weigth 100 day-old pigs from a high health status herd raised at the Embrapa Swine and Poultry Research Centre, Concordia-SC, Brazil, facilities were used in this study. The source herd has been negative for the main respiratory pathogens based on six monthly testing of tonsillar swabs for Pasteurella multocida type A and D, Bordetella bronchiseptica, Actinobacillus pleuropneumoniae, Haemophilus parasuis and Streptococcus suis by bacterial isolation; Nested-PCR and PCR (Mycoplasma hyopneumoniae and A. pleuropneumoniae, respectively) and ELISA test (M. hyopneumoniae and Porcine Reproductive and Respiratory Syndrome Virus - PRRS). Circulating antibodies against influenza A virus were detected on basal levels by ELISA, however, no viral genetic material was detected by RT-PCR test. Furthermore, respiratory diseases, such as enzootic pneumonia, influenza, polyserositis or Glässer's disease, atrophic rhinitis, pleuropneumonia and pasteurellosis have never been diagnosed since the farm was populated with caesarean derived animals in 2009. The farm respects strict biosecurity guidelines and has health barriers, closed rooms with positive internal pressure, visit restrictions and regular monitoring.

The animals were transferred from the farm to the isolation unit facilities (biosafety level 2) at the premises of the Animal Health and Genetics Laboratories at Embrapa Swine and Poultry, Concordia-SC, Brazil. Each group was housed in a different room, two pigs per pen, receiving food and water "ad libitum". Access to animals was restricted to the staff responsible for the experiment.

Before inoculation, two swabs were obtained from each pig, one from the palatine tonsils and one from the nasal cavity. A pool of these two swabs was cultured using routine methods for the isolation of bacterial pathogens of the respiratory tract of pigs $(A$. pleuropneumoniae, H. parasuis, B. bronchiseptica and P. multocida) (Quinn et al. 2011). M. hyopneumoniae testing was undertaken through Nested PCR assay from individual tonsillar swabs, according to Yamaguti et al. (2008).

Bacteria culture and inoculum. The P. multocida serotype A, strain \#11246 from Embrapa Swine and Poultry Research Centre collection was used. This bacterial strain was isolated from pleura and lung swabs of a finishing pig from a farrow-to-finish farm with 200 sows in the state of Santa Catarina, Brazil, in 2007. The pig had severe respiratory disease and fibrinosuppurative pleuropneumonia. Some animals from the same herd were necropsied and mucopurulent pneumonia affecting large areas of the lung (approximately 60\%), diffuse pleurisy and adherence between the parietal and visceral pleura were present. These animals were positive to $M$. hyopneumoniae and Porcine Circovirus Type 2 (PCV2) by Immunohistochemistry assay (IHC) from lung and lymph nodes samples, respectively. The isolate was characterized based on phenotypic (Quinn et al. 2011) and molecular features to identified the KMT1 gene (species and Type-specific) and capsular classification by detection of hyaD-hyaC gene (P. multocida capsular Type A) (Townsend et al. 2001). Moreover, it were research the gene Virulence-associated genes encoding haemoglobin binding protein $h g b B$, filamentous haemagglutinin $p f h A$, dermonecrotoxin tox $A$ and transferrin-binding protein $t b p A$ were tested by PCR, according to Ewers et al. (2006) and Atashpaz et al. (2009).

The recovery of $P$. multocida type A from the stock was performed by culture on blood agar plates (Blood Agar Base, BD Difco ${ }^{\mathrm{TM}}$, $5 \%$ sheep's blood) incubated at $37^{\circ} \mathrm{C}$ for $18-24$ hours. A subculture on a Trypticase Soy Agar (TSA) plate (Difco ${ }^{\mathrm{TM}}$ ) was incubated at $37^{\circ} \mathrm{C}$ for $18-24$ hours. The identity of this isolate was confirmed by phenotypic standard (Quinn et al. 2011).

Four different concentrations of inocula were prepared. The seed consisted of a suspension of bacterial colonies of the third passage from the TSA medium in $0.9 \%$ sterile saline adjusted to 0.7 absorbance $(540 \mathrm{~nm})$. From this seed, a series of base 10 dilutions were prepared $(1: 10,1: 100$ and $1: 1000)$. Inoculum concentrations were confirmed by counting the CFU.

Study design. Four groups (G1, G2, G3 and G4) of two pigs each were challenged with different concentrations of $P$. multocida type A strain 11246 inoculum as follows: G1: $10^{8} \mathrm{CFU} / \mathrm{ml}$ (pigs 131 and 135); G2: $10^{7} \mathrm{CFU} / \mathrm{ml}$ (pigs 129 and 130); G3: $10^{6}$ $\mathrm{CFU} / \mathrm{ml}$ (pigs 140 and 142) and G4: $10^{5} \mathrm{CFU} / \mathrm{ml}$ (pigs 139 and 143). Each pig received $3.0 \mathrm{ml}$ (1.5 ml/nostril) of the inoculum, administered by slow intranasal drip with animals in a sitting position. Another two pigs (177 and 199) housed separately were used as negative controls and inoculated with $3 \mathrm{ml}$ sterile phosphate buffered saline - PBS (1.5 ml/nostril).

All pigs were clinically evaluated twice a day (8-9 a.m. and 4-5 p.m.), starting just prior to inoculation (day $0 \mathrm{am}$ ) and ending on the $4^{\text {th }}$ day post-inoculation (dpi). Rectal body temperature (with a digital thermometer), dyspnoea (evaluated with pigs lying 
down) and coughing ( 5 min. with pigs moving during feeding and cleaning of pens) were evaluated.

Necropsy and sampling. Pigs were euthanized by electrocution, bled and necropsied on the $4^{\text {th }}$ dpi. Pigs with clinical signs of severe pneumonia were euthanized immediately due to animal welfare. At necropsy, the type, distribution and severity of lung, pleural and pericardial lesions were recorded. Samples of lung, trachea, mediastinal lymph node, heart, pericardial sac, liver, kidney and spleen were collected for histopathology and bacteriology. One portion of each sample was preserved in $10 \%$ buffered formaldehyde for histopathology and immunohistochemistry (IHC) for P. multocida type A. The other fragment was placed in a sterile plastic bag and stored at $2-8^{\circ} \mathrm{C}$ for bacteriological examination. Whenever present, fibrinous exudates in the pleura, pericardium, peritoneum and joints were also collected aseptically for bacteriological examination.

Histopathology and Immunohistochemistry (IHC). Histopathological slides were prepared by routine procedures and stained with hematoxylin and eosin (Banks 1993). For IHC, a sheep hyperimmune serum against $P$. multocida was prepared. Briefly, the antigen was produced by growing $P$. multocida type A (\#11246) in TSB, inactivating the bacteria with $0.12 \%$ formaldehyde, centrifuging the culture at $12,000 \mathrm{~g}$ and washing the pellet obtained in phosphate buffered saline (PBS). The pellet was resuspended in PBS with thimerosal $(0.2 \mathrm{~g} / \mathrm{L})$ and stored at $4-8^{\circ} \mathrm{C}$. This inoculum was used in seven serial inoculations carried out in two sheep (one year of age) by intramuscular route, with the antigen adjusted in a spectrophotometer to a transmittance of $37 \%$ $(540 \mathrm{~nm})$. The first four doses were administered only with inactivated antigen at two-day intervals. For the last three doses the inactivated antigen was mixed with aluminium hydroxide $(\mathrm{AlOH})$ and administered every seven days.

After processing and microtomy, tissue fragments with 3-5 $\mu \mathrm{m}$ thickness were fixed on poly-L-lysine treated slides, dewaxed, hydrated, and then subjected to the following steps: antigen retrieval in tissues by microwave irradiation for $5 \mathrm{~min}$ at $700 \mathrm{~W}$ followed by enzymatic digestion with $0.04 \%$ pepsin $(\mathrm{pH} 7.8$ ) for 10 min at $37^{\circ} \mathrm{C}$; blocking of endogenous peroxidase with $\mathrm{H}_{2} \mathrm{O}_{2}$; incubation of sections for $2 \mathrm{~h}$ at $37^{\circ} \mathrm{C}$ covered with the anti-P. multocida primary sheep polyclonal antibody in a dilution of 1:500; incubation of sections for $30 \mathrm{~min}$ at $37^{\circ} \mathrm{C}$ with the LSAB ${ }^{\circledR} \mathrm{HRP}$ Kit (DakoCytomation ${ }^{\circledR}$ ); use of 3-amino-9-ethylcarbazole (AEC) for 5 min at $37^{\circ} \mathrm{C}$; and counterstaining with Mayer's haematoxylin for 1 min. PBS (pH 7.4) was employed for washings between each step. All tissues obtained in the experiment were subjected to this technique. A fragment of lung with lesions (in stock) from a previously inoculated pig with the same P. multocida type A isolate was used as a positive control and as a negative control different samples of normal specific pathogen-free (SPF) pig to P. multocida were used.

The specificity of the IHC technique was tested using swine tissues samples with typical lesions, experimentally infected with A. pleuropneumoniae, Actinobacillus suis, H. parasuis and M. hyopneumoniae. The Chi-square test $\left(X^{2}\right)$ was performed to demonstrate the association between the IHC and bacteriology results for the lung, pericardium, trachea, mediastinal lymph nodes, spleen and kidneys samples. Furthermore, the agreement, sensitivity and specificity of the IHC test were calculated adopting the bacteriology results as gold standard method.

Microbiology. All tissues, swab samples and exudates collected were plated on blood agar and MacConkey (Difco ${ }^{\mathrm{TM}}$ ) plates and incubated at $37^{\circ} \mathrm{C}$ for $24-48$ hours under aerobic conditions. A streak of Staphylococcus aureus was added to a replicate plate and incubated microaerophilically at $37^{\circ} \mathrm{C}$ for $24-48$ hours. The biochemical characterization of isolates was carried out according to Quinn et al. (2011).
Other pathogens. In order to verify the absence of other primary respiratory pathogens, the IHC test was carried out for PCV2 (Ciacci-Zanella et al. 2006), influenza A virus (Vincent et al. 1997) and M. hyopneumoniae in all lung samples. For PCV2 the test was also performed in mediastinal lymph nodes. In order to detect $M$. hyopneumoniae, a monospecific recombinant polyclonal antibody against lactate dehydrogenase (p36) of $M$. hyopneumoniae (Castro et al. 2009) with a 1:1800 dilution was used. The IHC procedure for $M$. hyopneumoniae was standardized by our group, applying the streptavidin-biotin-peroxidase method with the commercial kit (Kit LSAB ${ }^{\circledR}+$ System - HRP from DakoCytomation ${ }^{\circledR}$ ). The antigen retrieval was performed by immersing the slides in citrate buffer ( $\mathrm{pH}$ 6.0) and irradiating them in a domestic microwave for $5 \mathrm{~min}$ at $700 \mathrm{~W}$. The enzymatic digestion was then performed using pepsin at $0.04 \%$ diluted in $0.01 \mathrm{~N}$ hydrochloric acid (pH 7.8) for $10 \mathrm{~min}$ at $37^{\circ} \mathrm{C}$. Tissue sections were labelled with primary antibody (anti-P36) for $2 \mathrm{~h}$ at $37^{\circ} \mathrm{C}$. The final colour was attained with AEC solution for $5 \mathrm{~min}$ at $37^{\circ} \mathrm{C}$, and counterstaining with Mayer's haematoxylin for $2 \mathrm{~min}$.

Statistics. Descriptive analysis was performed and the overall result shown in tables.

\section{RESULTS}

All animals tested negative for all respiratory pathogens screened before inoculation. The strain of Pasteurella multocida (\#11246) used in this study was confirmed as type capsule A based on biochemical and the molecular assays. Furthermore, as determined by PCR, this strain was positive for $h g b B$ and $p f h A$ genes and negative for tox $A$ and $t b p A$ genes.

\section{Clinical signs}

Due to animal welfare reason, five pigs with severe respiratory clinical signs were euthanized before the $4^{\text {th }} \mathrm{dpi}$ as follows: pigs 135 (G1) and 130 (G2) on the $1^{\text {st }} \mathrm{dpi}$, pig 140 (G3) on the $2^{\text {nd }} \mathrm{dpi}$ and the pig 131 (G1) and 143 (G4) on the $3^{\text {rd }} \mathrm{dpi}$. Fever and dyspnoea were observed in all challenged pigs. The rectal body temperature (Fig.1) increased in the first $6 \mathrm{~h}$ after challenge in G1, G2 and G3, with subsequent oscillation between physiological temperatures (39.1 to $\left.39.5^{\circ} \mathrm{C}\right)$ and hyperthermia $\left(>39.5^{\circ} \mathrm{C}\right)$ until euthanasia. In the G4 pigs, temperatures higher than $40^{\circ} \mathrm{C}$ were observed only on the $3^{\text {rd }} \mathrm{dpi}$ for pig $143\left(41.5^{\circ} \mathrm{C}\right)$ and on the $4^{\text {th }} \mathrm{dpi}$ for pig $139\left(41.1^{\circ} \mathrm{C}\right)$. In pigs of the G1 and G3 groups, dyspnoea was detected from the sixth hour post-inoculation until the $4^{\text {th }} \mathrm{dpi}$, and in G2 dyspnoea was verified from the $1^{\text {st }}$ to the $4^{\text {th }}$ dpi. In G4, dyspnoea occurred later, from the $3^{\text {rd }}$ to $4^{\text {th }}$ dpi. Coughing was observed only in pig 129 of G2, from the $1^{\text {st }}$ to $4^{\text {th }} \mathrm{dpi}$.

\section{Gross pathology}

Suppurative cranioventral bronchopneumonia with pleuritis (Figs.2 and 3) and fibrinous pericarditis (Fig.4) were observed in all challenged pigs of G1, G2 and G3 (Table 1). In these pigs, the total area of bronchopneumonia was more extensive, especially in pig 129 of G2 (27.2\%). In G4, animal 139 had a discrete area of consolidation (0.7\%) in the left cardiac lobe. In animal 143 (G4) only fibrinous pleuritis and pericarditis were observed. Locally extensive necrosuppurative pleuropneumonia, interpreted as $A$. pleuropneumoniae-like lesions, was observed in areas of 

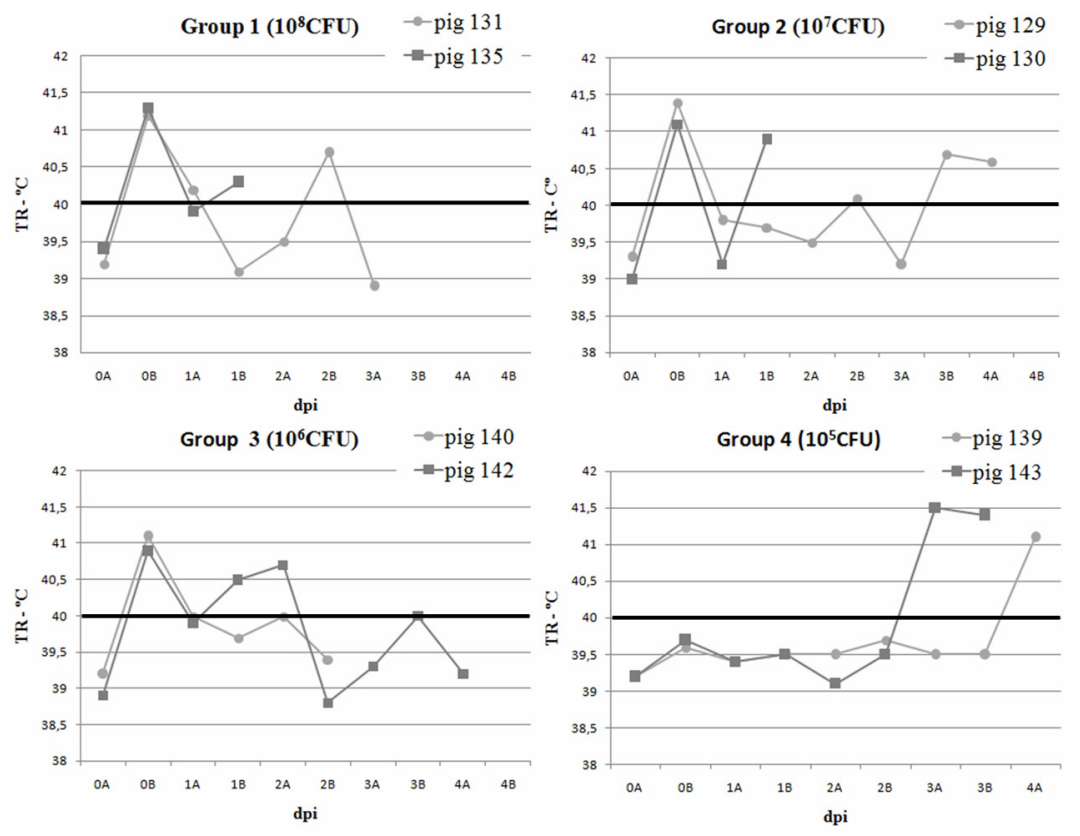

Fig.1. Rectal body temperature (RT) of pigs inoculated with Pasteurella multocida A (strain \#11246), G1: 10 CFU G2: 107 CFU; G3: $10^{6}$ CFU; G4:10 $0^{5}$ CFU. Group 1 and 2: first daily clinical evaluation (8-9 a.m.), Group 3 and 4: second daily clinical evaluation (4-5 p.m.).
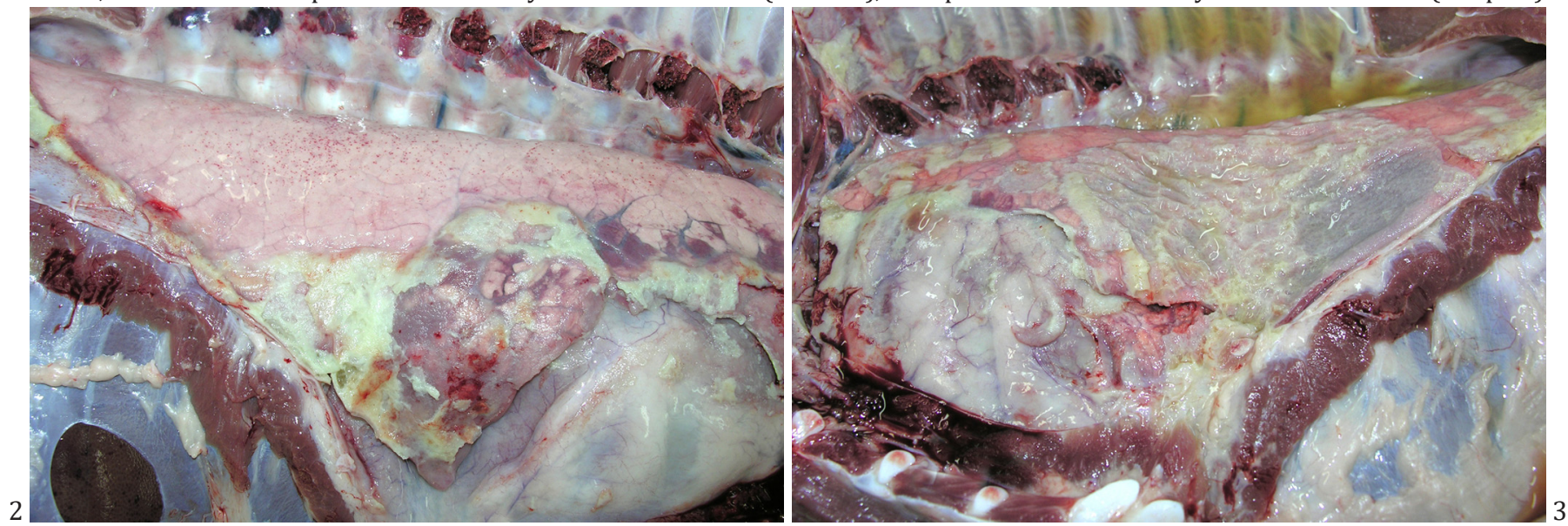

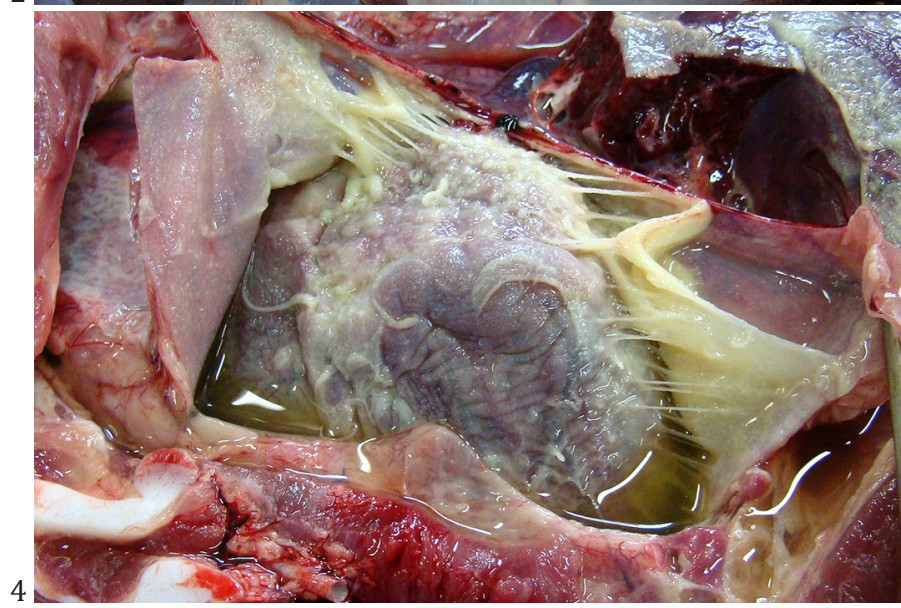

Fig.2. Right lung, pig 129 (G2) inoculated with $10^{7}$ CFU of Pasteurella multocida type A (strain \#11246). Cranioventral suppurative bronchopneumonia with focally extensive fibrinous pleuritis.

Fig.4. Pericardium sac and heart, pig 140 (G3) inoculated with $10^{6}$ CFU of Pasteurella multocida type A (strain \#11246). Diffuse fibrinous pericarditis.

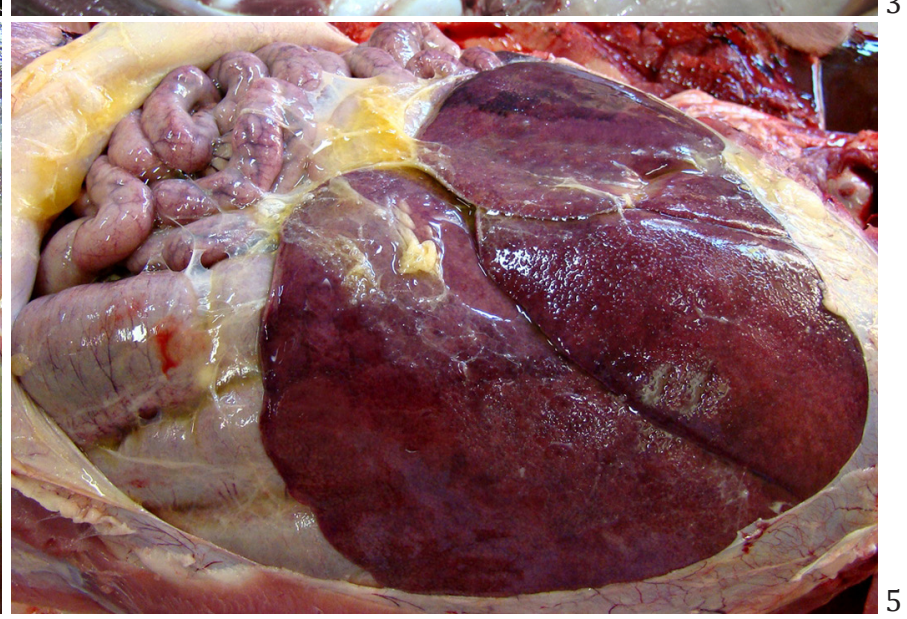

Fig.3. Left lung, pig 129 (G2) inoculated with $10^{7}$ CFU of Pasteurella multocida type A (strain \#11246). Diffuse fibrinous pleuritis.

Fig.5. Abdominal cavity, pig 143 (G4) inoculated with $10^{5} \mathrm{CFU}$ of Pasteurella multocida type A (strain \#11246). Diffuse fibrinous peritonitis. 
cranioventral bronchopneumonia in pigs 131 and 135 of G1, and 129 of G2. Mediastinal lymph nodes of all pigs were enlarged, juicy and red.

Fibrinous peritonitis was observed in pigs 130 (G2), 140 (G3) and 143 (G4) (Fig.5). In addition, increased synovial fluid with cloudy appearance was verified in the tibio-fibulo-tarsal joint of pig 140 (G3) and areas of splenic infarction in pig 143 (G4). For all challenged pigs, no macroscopic lesions were found in the myocardium, trachea, liver and kidneys.

\section{Histopathology}

Fibrinosuppurative pleuritis (Fig.6) and bronchopneumonia were observed in all challenged pigs of groups G1, G2 and G3. In addition, necrosuppurative bronchopneumonia (Fig.7), characterized by areas of coagulative necrosis in the alveolar parenchyma, with abundant neutrophils, fibrin (Fig.7 Inset). Bacteria was also observed in all animals of G1, G2 and G3. Some of these areas were surrounded by immature connective tissue. Lesions in the pleura and pe-

\section{Table 1. Number of pigs in each of four groups with macroscopic after intra-nasal challenge with Pasteuralla multocida A strain \#11246}

\begin{tabular}{lccccc}
\hline Lesion & \multicolumn{5}{c}{$\begin{array}{c}\text { Pasteurella multocida } \\
\text { inoculation group }\end{array}$} \\
\cline { 2 - 6 } & G1 & G2 & G3 & G4 & Control \\
\hline $\begin{array}{l}\text { Supurative fibrinous pleuritis } \\
\text { Cranioventral suppurative }\end{array}$ & 2 & 2 & 2 & 1 & - \\
bronchopneumonia & 2 & 2 & 2 & 1 & - \\
Locally extensive necrotic & 2 & 2 & 2 & - & - \\
suppurative pleuropneumonia & & & & & \\
Fibrinous pericarditis & & & & & - \\
Supurative lymphadenitis & 2 & 2 & 2 & 1 & - \\
Fibrinous peritonitis & 2 & 2 & 2 & 2 & - \\
Multifocal necrotizing hepatites & - & 1 & 1 & 1 & - \\
Focal necrotic splenitis & 1 & 1 & 1 & 1 & - \\
& - & - & - & 1 & -
\end{tabular}

a Two pigs per group, Group $1=10^{8} \mathrm{CFU}$ (Colony Forming Unit), Group 2 $=10^{7} \mathrm{CFU}$, Group $3=10^{6} \mathrm{CFU}$, Group $4=10^{5} \mathrm{CFU}$; ${ }^{\mathrm{b}}$ Lesion App like; $-\mathrm{Ab}-$ sence.

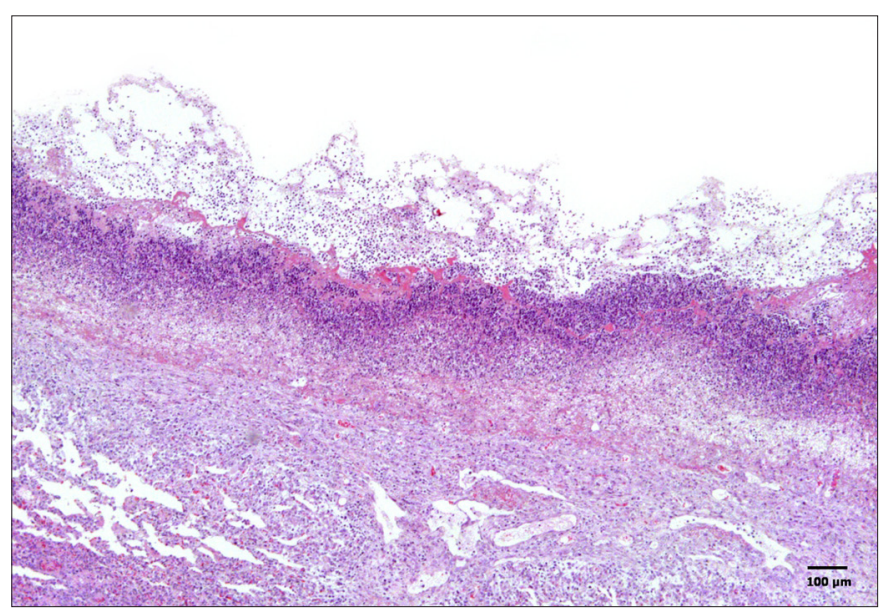

Fig.6. Lung, pig 129 (G2) inoculated with $10^{7}$ colony forming units (CFU) of Pasteurella multocida type A (strain \#11246). The pleura is thickened with a layer of fibrin, abundant neutrophils and necrotic debris. The underlying pulmonary parenchyma is atelectatic. HE. Bar, $100 \mu \mathrm{m}$.

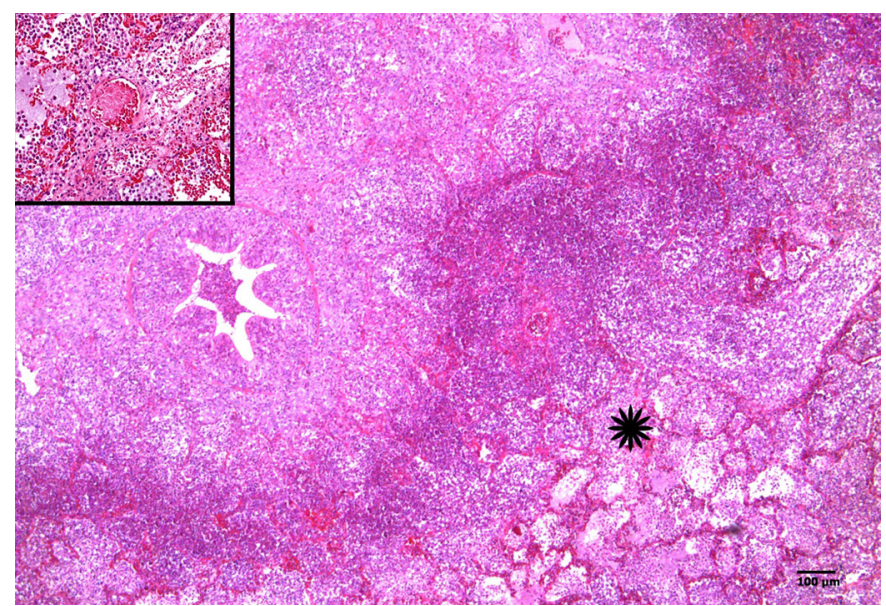

Fig.7. Lung, pig 131 (G1) inoculated with $10^{8}$ colony forming units (CFU) of Pasteurella multocida type A (strain \#11246). Suppurative bronchopneumonia with focally extensive area of coagulative necrosis within the pulmonary parenchyma $\left(^{*}\right)$. The edges of the necrotic area contain a rim of degenerated inflammatory cells, mainly neutrophils. HE, Bar $100 \mu \mathrm{m}$. Inset: a vessel is plugged with fibrin (fibrin thrombus); the interlobular septa is expanded by fibrin, and the alveoli are filled with neutrophils. HE. Bar $20 \mu \mathrm{m}$.

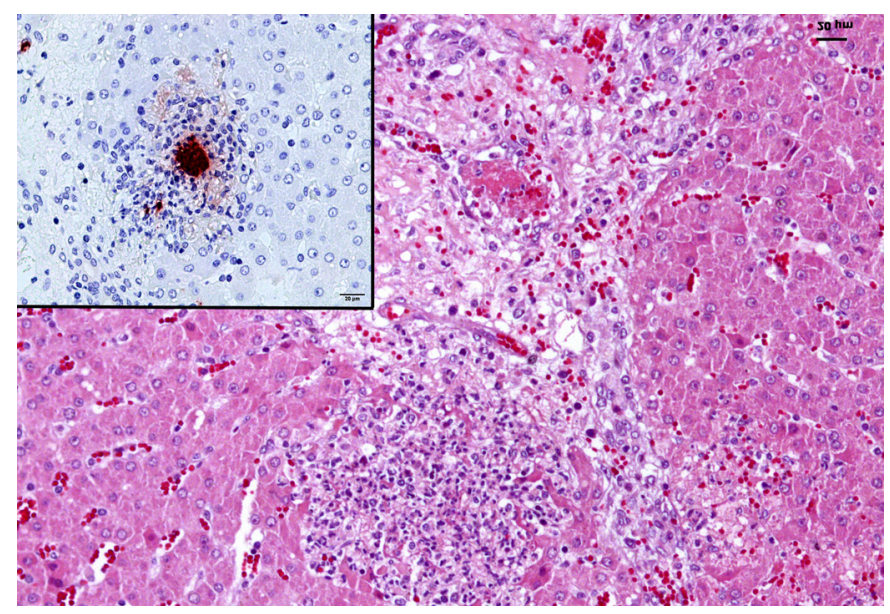

Fig.8. Liver, pig 135 (G1) inoculated with $10^{8}$ colony forming units (CFU) of Pasteurella multocida type A (strain \#11246). Focus of coagulative necrosis in the liver associated with a thrombus (arrow). HE. Bar, $50 \mu \mathrm{m}$. Inset: Focal aggregate of $P$. multocida antigen within necrotic focus. Bar, $20 \mu \mathrm{m}$. Immunohistochemistry, labelled streptavidin biotin (LSAB) method with 3-amino-9-ethylcarbazol (AEC) substrate, Mayer's haematoxylin counterstain.

ricardium were characterized by abundant fibrinosuppurative exudate on serosa and, in some cases, the presence of immature connective tissue. In mediastinal lymph nodes there was congestion, oedema, mild haemorrhage and numerous neutrophils. These lesions were especially located on the subcapsular and paratrabecular sinuses. In the liver lesions indicative of septic infarction were observed in at least one pig of each group, characterized by random multifocal necrotizing hepatitis with fibrin thrombi in portal vessels and mild macrophage infiltration (Fig.8).

In the kidneys, slight alterations consisting of interstitial 
haemorrhage and degeneration of tubular epithelium were observed in pigs 135 (G1) and 143 (G4). Fibrin thrombi were observed in the liver and spleen of pigs 135 (G1), 140 (G3) and 143 (G4). For all pigs, no gross and histological lesions were detected in the trachea and myocardium.

\section{Recovery of Pasteurella multocida}

P. multocida type A was isolated from the lung tissue of all challenged pigs (Table 2). P. multocida type A was also found, with highest frequency in the visceral portion of the pericardial sac (8/8), followed by the visceral pleura, trachea and spleen $(7 / 8)$, the mediastinal lymph nodes and peritoneum swabs $(6 / 8)$, the kidney $(5 / 8)$ and the tibio-fibulo-tarsal joint of pig 140 of G3 (1/8). The growth of $P$. multocida type A was dense and obtained in pure culture in all isolates.

All P. multocida type A recovered colonies had similar characteristics to the strain used in the inoculum. The identity was confirmed by the following biochemical tests: positive to catalase, oxidase, indole, nitrate, glucose, sucrose, mannitol and hyaluronidase; and negative to urease, lactose and acriflavine.

\section{IHC}

P. multocida antigen detected by IHC was located in several tissues (Table 2) with highest frequency in the lung and mediastinal lymph nodes $(7 / 8)$, followed by the pericardium sac (5/8), the spleen, liver and kidney $(4 / 8)$ and the trachea (3/8). There was no P. multocida detected in the myocardium. Abundant labelling was registered in the lung, especially in the cytoplasm of neutrophils and free in the exudate of necrotic areas (Fig.9). Also, abundant labelling of the P. multocida antigen was verified in the fibrinosuppurative exudate of the pericardium and pleura. Bacteria were seen in the lumen of blood vessels, in the trachea, kidney and liver (pigs 135, 140 and 143), in the spleen and peri-

Table 2. Number of pigs in each of four groups testing positive for Pasteurella multocida in bacteriological (BAC) and immunohistochemistry (IHC) tests following intra-nasal challenge with $P$. multocida A strain 11246

\begin{tabular}{|c|c|c|c|c|c|c|c|c|c|c|}
\hline \multirow{3}{*}{ Clinical Samples } & \multicolumn{10}{|c|}{ Pateurella multocida inoculation Group ${ }^{a}$} \\
\hline & \multicolumn{2}{|c|}{ G1 } & \multicolumn{2}{|c|}{ G2 } & \multicolumn{2}{|c|}{ G3 } & \multicolumn{2}{|c|}{ G4 } & \multicolumn{2}{|c|}{ Control } \\
\hline & $\mathrm{BAC}$ & IHC & BAC & IHC & BAC & IHC & BAC & IHC & BAC & $\mathrm{IHC}$ \\
\hline $\begin{array}{l}\text { Thoracic } \\
\text { cavity fluid }\end{array}$ & 2 & $\mathrm{ND}^{\mathrm{b}}$ & 2 & ND & 2 & ND & 1 & ND & 0 & 0 \\
\hline Visceral pleura & 2 & ND & 2 & ND & 2 & ND & 1 & ND & 0 & 0 \\
\hline Lung & 2 & 2 & 2 & 2 & 2 & 2 & 2 & 1 & 0 & 0 \\
\hline Pericardium & 2 & 1 & 2 & 1 & 2 & 2 & 2 & 1 & 0 & 0 \\
\hline Trachea & 2 & 1 & 2 & 0 & 2 & 1 & 1 & 1 & 0 & 0 \\
\hline $\begin{array}{l}\text { Mediastinal } \\
\text { lymph nodes }\end{array}$ & 2 & 2 & 2 & 2 & 1 & 1 & 1 & 2 & 0 & 0 \\
\hline $\begin{array}{l}\text { Abdominal } \\
\text { cavity }\end{array}$ & 2 & ND & 2 & ND & 1 & ND & 1 & ND & 0 & ND \\
\hline Liver & ND & 1 & ND & 1 & ND & 2 & ND & 1 & 0 & 0 \\
\hline Spleen & 2 & 1 & 1 & 1 & 2 & 1 & 2 & 1 & 0 & 0 \\
\hline Kidneys & 1 & 1 & 1 & 1 & 2 & 1 & 1 & 1 & 0 & 0 \\
\hline $\begin{array}{l}\text { Tibio fibular } \\
\text { tarsal joint }\end{array}$ & 0 & 0 & 0 & 0 & 1 & ND & 0 & ND & 0 & 0 \\
\hline
\end{tabular}

a Two swine per group, Group $1=10^{8} \mathrm{CFU}$ (Colony Forming Unit) $\mathrm{m}$ Group $2=10^{7} \mathrm{CFU}$, Group $3=10^{6} \mathrm{CFU}$, Group $4=10^{5} \mathrm{CFU}$; ${ }^{\mathrm{b} D}=$ Not done.

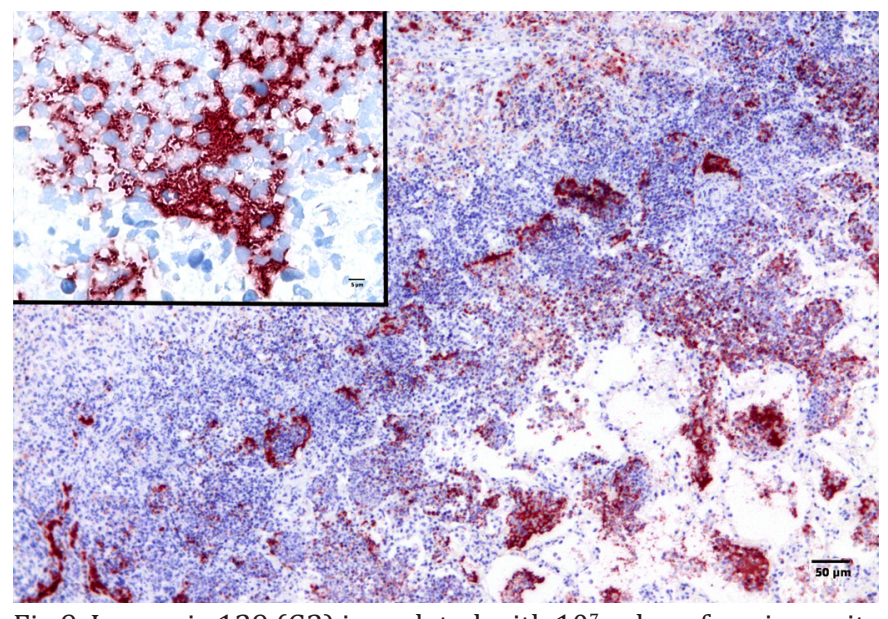

Fig.9. Lung, pig 129 (G2) inoculated with $10^{7}$ colony forming units (CFU) of Pasteurella multocida type A (strain \#11246). Abundant labelling of $P$. multocida antigen in the necrotic pulmonary parenchyma. Bar, $50 \mu \mathrm{m}$. Inset: Distinct labelling of antigen free P. multocida and within the cytoplasm of neutrophils and macrophages. Bar, $5 \mu \mathrm{m}$. Immunohistochemistry, labelled streptavidin biotin (LSAB) method with 3-amino-9-ethylcarbazol (AEC) substrate, Mayer's haematoxylin counterstain.

cardium (pig 135) and in the lymph node (pig 140), characterizing the septicaemia. In the liver, labelling was recorded in the lumen of blood capillaries and, in lower amounts, in the cytoplasm of macrophages in necrotic lesions (Fig.8 Inset) and in Kupffer cells. In the kidney, in addition to the antigen labelling in the lumen of the blood vessels mentioned above, there was also labelling in the cytoplasm of some macrophages and in the tubular interstitium in pig 130 (G2). In mediastinal lymph nodes the labelling occurred in the cytoplasm of some macrophages and in the lumen of capillaries and in the lumen of lymphatic and blood vessels.

The chi-square test showed an association between the IHC test and bacteriology results $(p<0.0001)$ and the agreement between these tests was $77.9 \%$. Adopting the bacteriology assay as a reference, the IHC test showed low sensitivity $(71.8 \%)$ and moderate to high specificity (90\%). Out of the 41 samples which tested positive for the detection of P. multocida, $68.3 \%(28 / 41)$ of the cases were positive by both techniques, $26.8 \%$ (11/41) only by bacterial isolation and $4.9 \%(2 / 41)$ only by IHC.

All tissue samples tested were negative for Mycoplasma hyopneumoniae, influenza A virus and Porcine circovirus Type 2 (PCV2) antigens by IHC. The two control pigs remained healthy throughout the experiment, and none of the infectious agents investigated were found.

\section{DISCUSSION}

Based on clinical and laboratorial findings of the present study we could demonstrate that Pasteurella multocida type A acted as the primary cause of respiratory disease in the experimental pigs from all infected groups, characterized by lung lesions and septicaemia, with no association with other infectious agents such as Mycoplasma hyopneumoniae, Actinobacillus pleuropneumoniae, Haemophilus parasuis, influenza virus A, PCV2 and PRRS. 
In this study, the clinicopathological characteristics of fibrinous pleuritis, suppurative bronchopneumonia with or without necrosuppurative pleuropneumonia, pericarditis and septicaemia in pigs challenged by an intranasal drip of $3 \mathrm{ml}$ of inoculum containing $10^{5}-10^{8} \mathrm{CFU} / \mathrm{ml}$ were replicated. Although the experimental reproduction of pneumonia, septicaemia and arthritis after inoculation with $P$. multocida type A had been previously reported (Ono et al. 2003), this was only possible through intratracheal inoculations containing $3.6 \times 10^{6}-6.2 \times 10^{10} \mathrm{CFU} / \mathrm{ml}$. Using the intranasal challenge with the same inoculum, these authors reproduced only histological lesions of exudative bronchopneumonia and fibrinous pleuritis. Other attempts of experimental reproduction of this infection challenging solely P. multocida type A and using other routes have not been successful (Ross 2006).

Since there was no established experimental model for this type of testing for pneumonia caused by P. multocida type A as the primary agent, there were no recommendations for the appropriate dose and route of inoculation. The choice of the dose was based on the results of previous experiments on pneumonia reproduction, even though they were not completely successful (Ono et al. 2003, Ross 2006, Dagleish et al. 2010). In these experiments, dose concentrations were usually between $10^{6}$ to $10^{9} \mathrm{CFU}$ and the most successful results were achieved using the intra-tracheal route. Based on the data available and on the previous work carried out by our group (Kich et al. 2007), concentrations of between $10^{5} \mathrm{CFU}$ to $10^{8} \mathrm{CFU}$ were used, and successful in dose $10^{6} \mathrm{CFU}$ and above.

Pigs challenged with inocula with higher bacterial concentration (G1, G2 and G3) developed pronounced clinical symptoms of pneumonia, characterized by severe dyspnoea, high hyperthermia and prostration six hours after inoculation with $P$. multocida type A. The severity of the lesions in the pleura, pericardium and bronchopneumonia resulting in reduced air spaces explains these symptoms (López 2007, Register et al. 2012, Vanalstine 2012). Hyperthermia peak occurred within the first six hours in pigs of G1, G2 and G3 with some oscillations in the physiological and temperature parameters. This is probably due to the compensatory mechanism of the body related to homeostasis (Bartfai \& Conti 2010). Dyspnoea and hyperthermia occurred later in pigs of group G4 ( $3^{\text {rd }}$ and $\left.4^{\text {th }} \mathrm{dpi}\right)$, but sufficiently severe to lead to the spontaneous death of pig 143 on the $3^{\text {rd }} \mathrm{dpi}$. The importance of the dose used in the experiment model was best represented in G4, where clinical signs were delayed but profuse isolation of $P$. multocida from several tissues was observed, especially in pig 143. Over time, it is possible that the clinicopathological picture could evolve to the same levels observed in the other groups (G1, G2 and G3). Coughing was not a consistent clinical sign and this may be explained by the pathogenesis, wherein $P$. multocida type A does not injure the epithelium of bronchi and bronchioles, in contrast to infections by $M$. hyopneumoniae and by the influenza A virus that have a tropism for the respiratory epithelium (DeBey \& Ross 1994, Gauger et al. 2012).

Necrosuppurative bronchopneumonia, fibrinosuppura- tive pleuritis and pericarditis prevailed in pigs challenged with all bacterial concentrations tested, except for G4 (Table 1). The pathological difference found between pigs challenged with the same inoculum concentration is probably derived from the individual response to the challenge. This was also evident in the IHC analysis, where even at low concentrations of inoculum, different labelling distribution of the P. multocida antigen in lesions was observed. Additionally, it is possible that part of the inoculum had been swallowed by some animals during inoculation and thus the bacterial concentration effectively inoculated may have been lower than preconized. Considering the successful reproduction of pneumonia and the distribution of the bacteria in different tissues after challenge with $P$. multocida type A strain 11246 by intranasal route, the use of inoculum doses of $10^{6}-10^{8} \mathrm{CFU}$ can be recommended. Even though there is no information in the literature regarding the minimum infectious dose under natural conditions, it is important to clarify that the use of high doses of $P$. multocida type A are only possible under experimental conditions. Nevertheless, similar studies have not been successful with equivalent or higher doses in the reproduction of the disease, with P. multocida type A as the primary agent of pneumonia, pleurisy and septicaemia (Ross 2006). These findings indicate the importance of the strain of P. multocida (strain \#11246) used in the challenge and suggests the genetic diversity of circulating strains in pig herds with a direct influence on the pathogenicity of the bacteria (Moreno et al. 2003, Ewers et al. 2006, Marois et al. 2009, Pors et al. 2011b).

As described above and in other studies (Pijoan \& Fuentes 1987, Ono et al. 2003), P. multocida type A can induce pleuritis and pericarditis which leads to speculation that certain isolates of $P$. multocida type A may play an important role in chronic lesions of pleurisy and pericarditis observed in pigs at slaughter (Jirawattanapong et al. 2010), which are responsible for significant economic losses. In our study, in addition to these lesions, P. multocida was also the cause of peritonitis and arthritis, demonstrating the importance of differentiating the diagnosis from that of polyserositis caused by H. parasuis (Aragon et al. 2012). As we did not find a clear pattern of injury in other organs among groups, further studies are necessary to clarify the methods of invasion of $P$. multocida.

At necropsy, locally extensive necrosuppurative pleuropneumonia was found in the pigs of G1 and in pig 129 of G2. However, microscopically, necrosuppurative bronchopneumonia was detected in all pigs in macroscopic areas of cranioventral bronchopneumonia, except those of $\mathrm{G} 4$. It is possible that the bacterial concentration is associated with the pathological alterations observed and with the evolution of the disease, including the case of the pigs in G4 group. These lesions are considered to be $A$. pleuropneumoniae-like, because they are similar to those produced by A. pleuropneumoniae (Gottschalk 2012) by means of RTX (repeats in the structural toxin) toxins (Frey 2011). As described in this study, the lesions of pulmonary necrosis were predominantly suppurative, which differs from A. pleuropneumoniae which is predominantly haemor- 
rhagic. Moreover, in these lesions induced by P. multocida type A the presence of few oat cells was verified, which are abundant in lesions produced by A. pleuropneumoniae (Gottschalk 2012). Actinobacillus pleuropneumoniae-like pulmonary lesions associated with the isolation of $P$. multocida type $\mathrm{A}$ and $\mathrm{D}$ and negative results for A. pleuropneumoniae have been reported in field studies (Cappuccio et al. 2004). The higher pathogenicity of this P. multocida type A isolate and the development of A. pleuropneumoniae-like lesions may indicate possible genetic and virulence differences between distinct isolates (Davies et al. 2003, Ewers et al. 2006, Bethe et al. 2009, Pors et al. 2011b), which highlights the need for further studies on this topic.

P. multocida type A strain 11246 showed a high tissue spreading rate, where the liver, kidney and spleen being important organs for detecting P. multocida in cases of sepsis in pigs, which conflicts with the results of Pors et al. (2011a). In the study, there was septicaemia at all inoculum concentrations, characterized by infarcts, mainly in the liver and spleen, and the presence of the bacterium in different organs detected by bacterial isolation and IHC. Overall, bacterial isolation demonstrated higher levels of detection of P. multocida type A when compared to IHC, with an agreement of $77.8 \%$ between the results of the two tests. Despite showing lower sensitivity than the bacteriological assay, the IHC test can be used to demonstrate the presence of bacteria in a lesion and it can be used as an additional tool for the study of the pathogenesis of P. multocida infection in pigs.

The occurrence of septicaemia has also been observed in infections with P. multocida serotype B in birds, buffaloes and pigs (Davies et al. 2003, Ewers et al. 2006). Septicaemia in pigs caused by P. multocida type A has been described in a few experimental studies (Smith et al. 1973, Ono et al. 2003) and in cases of natural infections (Pijoan \& Fuentes 1987, Mackie et al. 1992, Cameron et al. 1996, Blackall et al. 2000; Thomson et al. 2001, Pors et al. 2011a). According to these publications, both experimental and natural infections have resulted exclusively in respiratory disease, and this may suggest the existence of strains expressing different determinants of pathogenicity, and some expressing factors determining the invasiveness of the bacteria.

The pleuropneumonia lesions found in this study, with the exception of A. pleuropneumoniae-like lesions, were similar to those found in cattle infected by Mannhemia haemolytica (formerly Pasteurella haemolytica) (Singh et al. 2011). These agents along with P. multocida type A and A. pleuropneumoniae belong to the family Pasteurellaceae, suggesting a possible similarity of pathogenicity between these bacteria involving virulence factors. Among the virulence-associated genes of $P$. multocida, Ewers et al. (2006) reported that genes encoding tox $A, t b p A$ and $p f h A$, as well as capsule biosynthesis genes, are potential genetic markers of pathogenicity. The isolate of $P$. multocida type A used in this study contained the genes $p f h A$ and $h g b B$, suggesting that these may be genetic markers of the pathogenicity of the bacterium. However, to prove it, it is necessary to compare the presence and functionality of these genes present in bacteria isolated from healthy and diseased pigs.
Historically, P. multocida has been considered as a secondary agent in the Porcine Respiratory Disease Complex (PRDC) (Pijoan \& Fuentes 1987, Choi et al. 2003; Hansen et al. 2010). Several studies have been able to experimentally replicate pneumonia only when $P$. multocida type A is associated with other infectious or non-infectious co-factors, such as influenza A virus and pseudorabies (SuidHerpesvirus 1), M. hyopneumoniae, Ascaris suum, fumonisin, high environmental levels of ammonia and anaesthetics (Ross 2006). However, the sample of $P$. multocida type A strain 11246 used in this study was the cause of severe clinicopathological condition associated with fibrinous pleuritis, suppurative bronchopneumonia and necrosuppurative pleuropneumonia in finishing pigs, in the absence of other pulmonary agents, being thus considered as the primary agent.

The lesions obtained by experimental reproduction were similar to those found in animals in the herd where the strain \#11246 had been isolated. These results suggest that the strain had the same pathogenic characteristics under field and experimental conditions. However, this needs further investigation, since many aspects of the pathogenesis of $P$. multocida infection in pigs still remain unclear (Ewers et al. 2006, Bethe et al. 2009, García et al. 2011). Due to the similarities between the gross and microscopic lesions caused by P. multocida in the present study and those caused by other bacteria of the family Pasteurellaceae (H. parasuis and A. pleuropneumoniae), it is essential to perform laboratory tests to achieve a differential diagnosis. With the present infection model, further studies including a greater number of strains of $P$. multocida type A can be carried out to identify phenotypic and genetic differences among strains involved in the pathogenesis of pneumonia in pigs.

Acknowledgements.- The authors are grateful to the Coordination of Improvement of Higher Education Personnel (CAPES) for the scholarship provided to João Xavier de Oliveira Filho; to Embrapa for funding the research project; to Dra. Márcia Cristina da Silva (Cedisa), Dra. Jalusa Deon Kich (Embrapa Swine and Poultry), Dr. Roberto M. Guedes (UFMG) and Dr. Ricardo Zenella (Early Investigator BJT/CNPq Embrapa Swine and Poultry) for intellectual support; and to Altair Althaus, Dejalmo A. da Silva, Franciele Ianiski, Franciana A. Volpato (Embrapa Swine and Poultry), and Kelen Ascoli (Cedisa) for valuable technical support.

Conflict of interest statement.- The authors have no competing interests.

\section{REFERENCES}

Aragon V., Segalés J. \& Oliveira S. 2012. Glässer's Disease, p.760-769. In: Zimmerman J.J., Karriker L.A., Ramirez A., Schwartz K.J. \& Stevenson G.W. (Eds), Diseases of Swine. 10th ed. Wiley-Blackwell, Ames, Iowa.

Atashpaz S., Shayegh J. \& Hejazi M.S. 2009. Rapid virulence typing of Pasteurella multocida by multiplex PCR. Res. Vet. Sci. 87:355-357.

Banks J.W. 1993. Applied Veterinary Histology. 3th ed. Mosby-Year Book, St Louis. 527p.

Bartfai T. \& Conti B. 2010. Fever. Scientific World Journal 10:490-503.

Bethe A., Wieler L.H., Selbitz H. \& Ewers C. 2009. Genetic diversity of porcine Pasteurella multocida strains from the respiratory tract of healthy and diseased swine. Vet. Microbiol. 139:97-105.

Blackall P.J., Fegan N., Pahoff J.L., Storie G.J., McIntosh G.B., Camerom R.D., O’Boyle D., Frost A.J., Bará M.R., Marr G. \& Holder J. 2000. The molecular 
epidemiology of four outbreaks of porcine pasteurellosis. Vet. Microbiol. 72:111-120.

Cameron R.D., O'Boyle D., Frost A.J., Gordon A.N. \& Fegan N. 1996. An outbreak of haemorrhagic septicaemia associated with Pasteurella multocida subsp gallicida in large pig herd. Aust. Vet. J. 73:27-29.

Cappuccio J., Leotta G.A., Vigo G., Moredo F., Wolcott M.J. \& Perfumo C.J. 2004. Phenotypic characterization of Pasteurella multocida strains isolated from pigs with bronco and pleuropneumonia. 18th International Pig Veterinary Society Congress, Hamburg, Germany, p.205.

Castro L.A., Schuck D., Mores N., Zaha A., Ferreira H.B. \& Driemeier D. 2009. Monospecific polyclonal antibodies for immunodetection of $M y$ coplasma hyopneumoniae in swine pneumonic lungs. Vet. Immunol. Immunopathol. 128:336-337.

Choi Y.K., Goyal S.M. \& Joo H.S. 2003. Retrospective analysis of etiologic agents associated with respiratory diseases in pigs. Can. J. Vet. Res. 44:735-737.

Ciacci-Zanella J.R., Morés N., Simon N.L., Oliveira S.R. \& Gava D. 2006. Identificação do circovírus suíno tipo 2 por reação em cadeia da polimerase e por imuno-histoquímica em tecidos suínos arquivados desde 1988 no Brasil. Ciência Rural 36:1480-1485.

Dagleish M.P., Finlayson J., Bayne C., MacDonald S., Sales J. \& Hodgson J.C. 2010. Characterization and time course of pulmonary lesions in calves after intratracheal infection with Pasteurella multocida A:3. J. Comp. Pathol. 142:157-169.

Davies R.L., MacCorquodale R., Baillie S. \& Caffrey B. 2003. Characterization and comparison of Pasteurella multocida strains associated with porcine pneumonia and atrophic rhinitis. J. Med. Microbiol. 52:59-67.

DeBey M. \& Ross R.F. 1994. Ciliostasis and loss of cilia induced by Mycoplasma hyopneumoniae in porcine tracheal organ cultures. Infect. Immun. 62:5312-5318.

Ewers C., Lübke-Becker A., Bethe A., Kießling S., Filter M. \& Wieler L.H. 2006. Virulence genotype of Pasteurella multocida strains isolated from different hosts with various disease status. Vet. Microbiol. 114:304-317.

Falk K., Høie S. \& Lium B.M. 1991. An abattoir survey of pneumonia and pleuritis in slaughter weight swine from 9 selected herds. II. Enzootic pneumonia of pigs: microbiological findings and their relationship to pathomorphology. Acta Vet. Scand. 32:67-77.

Frey J. 2011. The role of RTX toxins in host specificity of animal pathogenic Pasteurellaceae. Vet. Microbiol. 153:51-58.

García N., Fernández-Garayzábal J.F., Goyache J., Domínguez L. \& Vela A.I. 2011. Associations between biovar and virulence factor genes in Pasteurella multocida isolates from pigs in Spain. Vet. Rec. 169:362-366.

Gauger P.C., Vincent A.L., Loving C.L., Henningson J.N., Lager K.M., Janke B.H., Kehrli Jr M.E. \& Roth J.A. 2012. Kinetics of lung lesion development and pro-inflammatory cytokine response in pigs with vaccine-associated enhanced respiratory disease induced by challenge with pandemic (2009) A/H1N1 influenza virus. Vet. Pathol. 49:900-912.

Gottschalk M. 2012. Actinobacillosis, p.653-669. In: Zimmerman J.J., Karriker L.A., Ramirez A., Schwartz K.J. \& Stevenson G.W. (Eds), Diseases of Swine. 10th ed. Wiley-Blackwell, Ames, Iowa.

Hansen M.S., Pors S.E., Jensen H.E., Bille-Hansen V., Bisgaard M., Flachs E.M. \& Nielsen O.L. 2010. An investigation of the pathology and pathogens associated with porcine respiratory disease complex in Denmark. J. Comp. Pathol. 143:120-131.

Høie S., Falk K. \& Lium B.M. 1991. An abattoir survey of pneumonia and pleuritis in slaughter weight swine from 9 selected herds. IV. Bacteriological findings in chronic pneumonic lesions. Acta Vet. Scand. 32:395402 .

Jirawattanapong P., Stockhofe-Zurwieden N., Leengoed L.V., Wisselink H., Raymakers R., Cruijsen T., Van der Peet-Schwering C., Nielen M. \& Van Nes A. 2010. Pleuritis in slaughter pigs: relations between lung lesions and bacteriology in 10 herds with high pleuritis. Res. Vet. Sci. 88:11-15.
Kich J.D., Mores N., Triques N.J., Nogueira M.G., Locatelli C., Klein C.S. \& Felício R.P. 2007. Pasteurella multocida Tipo A atuaria como agente primário nos processos pneumônicos dos suínos? Comum. Téc. 469, Embrapa Suínos e Aves, Concórdia. 7p.

López A. 2007. Respiratory system, p.463-558. In: McGavin M.D. \& Zachary J.F. (Eds), Pathologic Basis of Veterinary Disease. 4th edition. Elsevier, Philadelphia.

Mackie J.T., Barton M. \& Kettlewell J. 1992. Pasteurella multocida septicaemia in pigs. Aust. Vet. J. 69:227-228.

Marois C., Fablet C., Gaillot O., Morvan H., Madec F. \& Kobisch M. 2009. Molecular diversity of porcine and human isolates of Pasteurella multocida. J. Appl. Microbiol. 107:1830-1836.

Moreno A.M., Baccaro M.R., Ferreira A.J.P. \& De Castro A.F.P. 2003. Use of single-enzyme amplified fragment length polymorphism for typing Pasteurella multocida subsp. multocida isolates from pigs. J. Clin. Microbiol. 41:1743-1746.

Ono M., Okada M., Namimatsu T., Fujii S., Mukai T. \& Sakano T. 2003. Septicaemia and arthritis in pigs experimentally infected with Pasteurella multocida capsular serotype A. J. Comp. Pathol. 129:251-258.

Pijoan C. \& Fuentes M. 1987. Severe pleuritis associated with certain strains of Pasteurella multocida in swine. J. Am. Vet. Med. Assoc. 191: 823-826.

Pors S.E., Hansen M.S., Bisgaard M. \& Jensen H.E. 2011a. Occurrence and associated lesions of Pasteurella multocida in porcine bronchopneumonia. Vet. Microbiol. 150:160-166.

Pors S.E., Hansen M.S., Christensen H., Jensen H.E., Petersen A. \& Bisgaard M. 2011b. Genetic diversity and associated pathology of Pasteurella multocida isolated from porcine pneumonia. Vet. Microbiol. 150:354-361.

Quinn P.J., Markey B.K., Leonard F.C., Fitzpatrick E.S., Fanning S. \& Hartigen P.J. 2011. Pasteurella species, Mannheimia haemolytica and Bibersteinia trehalosi, p.300-308 In: Ibid. (Eds), Veterinary Microbiology and Microbial Disease. 2nd ed. Wiley-Blackwell, Ames, Iowa.

Register K.B., Brockmeier S.L., Jong M.F. \& Pijoan C. 2012. Pasteurellosis, p.798-810. In: Zimmerman J.J., Karriker L.A., Ramirez A., Schwartz K.J. \& Stevenson G.W. (Eds), Diseases of Swine. 10th ed. Wiley-Blackwell, Ames, Iowa.

Ross R.F. 2006. Pasteurella multocida and its role in porcine pneumonia. Anim. Health Res. Rev. 7:13-29.

Singh K., Ritchey J.W. \& Confer A.W. 2011. Mannheimia haemolytica: Bacterial-host interactions in bovine pneumonia. Vet. Pathol. 48:338-348.

Smith I.M., Betts A.O., Watt R.G. \& Hayward A.H.S. 1973. Experimental infections with Pasteurella multocida (sero-group A) and an adeno- or enterovirus in gnotobiotic piglets. J. Comp. Pathol. 83:1-12.

Sørensen V., Jorsal S.E. \& Mousing J. 2006. Diseases of the respiratory system, p.149-177. In: Straw B.E., Zimmerman J.J., D’Allarie S. \& Taylor D.J. (Eds), Diseases of Swine. Blackwell Publishing, Oxford.

Thomson J.R., MacIntyre N., Henderson E.A. \& Meikle C.S. 2001. Detection of Pasteurella multocida in pigs with porcine dermatitis and nephropathy syndrome. Vet. Rec. 149:412-417.

Townsend K.M., Boyce J.D., Chung J.Y., Frost A.J. \& Adler B. 2001. Genetic organization of Pasteurella multocida cap loci and development of a multiplex capsular PCR typing system. J. Clin. Microbiol. 39:924-929.

Vanalstine W.G. 2012. Respiratory System, p.348-362. In: Zimmerman J.J., Karriker L.A., Ramirez A., Schwartz K.J. \& Stevenson G.W. (Eds), Diseases of Swine. 10th ed. Wiley-Blackwell, Ames, Iowa.

Vincent L.L., Janke B.H., Paul P.S. \& Halbur P.G. 1997. A monoclonalantibody-based immunohistochemical method for the detection of swine influenza virus in formalin-fixed, paraffin-embedded tissues. J. Vet. Diagn. Invest. 9:191-195.

Yamaguti M., Muller E.E., Piffer A.I., Kich J.D., Klein C.S. \& Kuchiishi S.S. 2008. Detection of Mycoplasma hyopneumoniae by polymerase chain reaction in swine presenting respiratory problems. Braz. J. Microbiol. 39:471-476. 